New Zealand Journal of Industrial Relations, 20(2): 119-141

\title{
Negotiation and Dictation in Employment Contract Formation in New Zealand
}

\author{
Ian McAndrew and Matt Ballard*
}

Previous research reports had identified and catalogued three apparently distinct employer approaches to the development of collective employment contracts under the Employment Contracts Act 1991: dealing directly with the workforce, dealing directly with employees individually, and dealing with employee representatives. This paper shows through further analysis of research data that the first two of these approaches are more properly grouped with the development of individual contracts under a non-negotiation model, in which employers rarely moved significantly from initial contract proposals once presented, and in which the rate of adoption of employee concessions proposed by employers was very high. In contrast is a largely unionised representative collective negotiations model, in which parties exhibited conventional bargaining behaviour, and in which the adoption rate of employer proposed employee concessions was significantly below that of the nonnegotiation model. Workforce size and pre-Act union strength are seen to be the primary factors associated with the likelihood of employers being involved in the unionised negotiation model.

Negotiation behaviours affecting employment conditions in New Zealand workplaces have been changing in important ways in recent years. While changes in the global and national economies have provided the backdrop, the dramatic revision of the regulatory regime in the labour market via the Employment Contracts Act of 1991 (the ECA or the Act) was what most directly changed the rules. The background to the Act has been widely reported (e.g.: Walsh and Ryan, 1993), and at the time of its introduction, there was a good deal of speculation as to both its motivation and likely impacts (e.g.: Anderson, 1991; Walsh, 1991). Certainly it was accepted that, whatever one's evaluation, the Act was intended to bring about substantial changes in the way in which employers and their employees interacted, in the way in which terms and conditions of employment were determined, and ultimately in those conditions of employment.

Department of Management, University of Otago. This research was funded by a grant from the Otago University Research Committee. The authors are grateful to employers who participated in the research, and to Bronwyn Boon. Virginia Phillips and Valerie Thompson for research assistance. Details of statistical procedures employed in the research are available on request from the authors. 
This paper is about the way in which employers and employees have interacted in the determination of terms and conditions of employment under the ECA. It extends previous work examining the various models of employment contract formation that have emerged under the Act. The paper begins by discussing several preliminary matters by way of background. The middle part of the paper reports our data on approaches to employment contract formation. Finally, we draw some conclusions from the data and relate those back to our introductory discussion points.

Employer behaviours and strategies are the starting point for our research. Walton and McKersie, in a contemporary introduction to the re-release of their 1965 classic work on negotiation behaviour (Walton \& McKersie, 1991), acknowledge as an important impact of global moves to a more competitive and cost-conscious marketplace, a reversal in the roles of labour and management in employment contract development. Where 30 years ago, labour unions were the moving party in contract formation and change, today employers are more likely to have the initiative and to set the agenda. Peter Boxall (1993: 148) has articulated the implications of this development for research locally:

Any genuine attempt to come to grips with the factors that led to the Employment Contracts

Act 1991 must deal with the reform agenda of New Zealand managers. Similarly, any attempt to understand what has actually changed in the practice of labour relations since the advent of the Act must consider the initiatives of management.

An earlier paper (McAndrew, 1993) identified three apparently distinct employer approaches to the development of collective employment contracts under the Act: dealing directly with the workforce, dealing directly with individual employees, and dealing with employee representatives (these being almost always union officials). The initial focus of the analysis reported in this paper was to examine the distribution of these three approaches, by reference to a number of organisational and industrial relations variables previously found to be associated with contract status and structure under the Act (McAndrew, 1992). In fact, the analysis points to the previous classification of approaches to collective contract formation as being an essentially cosmetic one, and suggests a dichotomous categorisation of employer approaches into "negotiation" and "non-negotiation" as being both more real and more helpful to understanding the processes of contract formation under the Act. Consequently, explaining the distribution of those two employer approaches or strategies, including importantly the linkages to workforce unionisation, becomes the ultimate focus of this paper.

Preliminarily, the paper turns first to a brief review of the bargaining provisions of the Act and to the relevant impacts of the Act, and second to a review of the rich literature that has long equated effective employee voice in the determination of employment conditions with unionisation. This theme will be seen to feature strongly in the conclusions to be drawn from the research results presented below. 


\section{The bargaining provisions of the ECA}

The principal bargaining provisions of the ECA have been detailed elsewhere. Walsh (1991) provides a full early account. A relatively briefer summary will suffice here.

Under the Act, each employee can elect to self-represent or to individually authorise one or more "bargaining agents" to act on his or her behalf. An employer must "recognise" an authorised bargaining agent, and the reach of that obligation continues to be the subject of judicial interpretation. Employers are also entitled to designate bargaining agents. Bargaining agent status is fluid and may be withdrawn at virtually any time.

Bargaining and contracts may be either individual or collective, and which they are is itself negotiable, as is the structure or coverage of any collective contract. The range of subjects for negotiation is also negotiable. No employer or employee may be covered by a collective contract without his or her individual consent. Bargaining agents may be parties to a contract only by agreement of the principal parties -- the employer(s) and the employee(s).

While virtually all procedural and substantive aspects of contract formation are subject to negotiation, there is no statutory obligation to negotiate and, accordingly, no standards of bargaining behaviour are expressly prescribed in the legislation. Whether negotiations will occur, with whom and about what, are all themselves negotiable questions. Strikes and lockouts are lawful in pursuit of collective contracts, except that strikes are not lawful where the intent is to form a multi-employer contract.

Individual contracts are actively encouraged over collective contracts, if only because rights attach to individuals rather than to collectives and because there are no procedural provisions in the law providing a foundation for collective bargaining.

There have, since the passage of the Act, been some important refinements of the bargaining provisions as the Courts have been called upon for interpretation of the statutory language. Some recent judicial pronouncements would be seen by most commentators as enhancing what was initially seen by many as only an inconsequential entitlement of employees to insist that their employer deal with them collectively through their common but individually designated bargaining agent in the negotiation of employment terms and conditions ${ }^{1}$. The implications of these recent judicial developments, in light of the research findings to be reported here, will be noted later in the paper.

\section{The relevant impacts of the Act}

The institutional and substantive characteristics and consequences of the labour market sponsored by the Employment Contracts Act have been regularly charted and evaluated since its inception. Beyond official sources (Armitage and Dunbar 1993; Whatman,

1 The most important development in this respect is the recent decision of Chief Judge Goddard of the Employment Court in Ivamy \& Ors \& The New Zealand Professional Firefighters Union v The New Zealand Fire Service Commission WEC44/95, July 14, 1995. 
Armitage and Dunbar 1994), the primary reporting has been by Professors Harbridge and Hince and their associates based in the Industrial Relations Centre at Victoria University of Wellington (Hammond and Harbridge 1993; Harbridge and Moulder 1993; Harbridge, Hince and Honeybone 1994; Harbridge and Hince 1994; Harbridge, Hince and Honeybone 1995). Hince and Harbridge (1994) provides an excellent summary assessment of what remains as the organised or collectivised sector based on the authors' databases on union membership and on voluntarily submitted collective employment contracts. They report "ten key findings" (Hince and Harbridge 1994: 237-238), a number of which are relevant to the present paper:

Overall coverage of collective bargaining in New Zealand declined from some 721,000 employees to approximately 370,000 , a decline of between 40 percent and 50 percent, in the three year period May 1991 to May 1994.

Average wage increases were very low in the first two years after the passage of the Act, but a wide variation in settlements emerged with some 10 percent of employees experiencing a decrease to basic rates, whilst other groups gained considerable increases. The traditional relativities and the notion of comparative wage justice disappeared quickly

The radical adjustment of relativities observed and reported during the 1991-92 and 1992-93 years seems to have been completed.

Clock hours remain in contracts covering 57 percent of the employee in the sample thus making them eligible for given premium payments for work undertaken after the completion of the 40 hour week.

Where premiums for penal and overtime still apply, they apply at broadly similar rates as they have previously.

Traditional unions remain the preferred choice of employees as their bargaining agent with over 85 percent of employees covered by collective contracts choosing a union negotiated contract ${ }^{2}$.

This portrait of the new industrial relations system reveals a collectivised sector reduced to about half of its former reach. Some part of it is unionised. And even within this collectivised sector, a marked diversification and discrimination of outcomes occurred quickly following the implementation of the Employment Contracts Act, and now appears to have been cemented in place.

2 This figure (perhaps amongst others) should be recognised as reflecting the particular sample of voluntarily submitted collective employment contracts that constitute the IRC database. Whatman, Armitage and Dunbar (1994:59) reported that "trade unions represented a higher proportion of employees in negotiations for collective contracts in the 1992-93 period than was the case in the 1991-92 period (up from 61 percent to 72 percent)". Those numbers are broadly consistent with our own research. The point being made by Professors Hince and Harbridge remains valid, however: to the extent that bargaining agents are being used by employees in the negotiation of collective contracts, those bargaining agents are union officials. This is a result that comes through clearly in our own research. 


\section{The literature in review}

Freeman and Medoff (1984: 8) wrote that, "a trade union is a vehicle for collective voice - that is, for providing workers as a group with the means of communicating with management." The union as a vehicle for effective employee input on employment conditions is an enduring theme in industrial relations literature and, as will be seen, one confirmed yet again in the present research.

Research and thought about trade unionism has moved through three fairly distinct periods over the past 100 years. The founding theories of trade unionism at the beginning of this century examined the trade union as an entity of social movement. The middle decades of the century represented the boom period in industrial relations research, and during this time research became more focused on collective bargaining as the principal activity of the union. Following the vast economic upheaval of the 1970s writers in the modern era have suggested that the study of industrial relations must transcend the traditional, formal institutions that regulate employer-employee relations. These writers believe that global competition, recession, deregulation and privatization have permanently changed the patterns of industrial relations.

The Webbs (1896: 1) described the trade union as a, "continuous association of wageearners for the purpose of maintaining or improving the conditions of their working lives." The union arises, according to the Webbs, to serve two roles: the restriction of numbers in a trade and the establishment of uniform minimum standards across firms. Perlman (1928) developed the thesis that a consciousness of scarcity of opportunity shapes economic attitudes within a workforce, and generates a sense of union solidarity. Tannenbaum (1921) argued that by joining unions workers could recover their social identity, create some sort of occupational community and develop new patterns of social interaction with their colleagues. Trade unions in this view are both a solution to social and economic needs, and a defensive mechanism against the competitive nature of the capitalist system. As Kochan (1995: 5) notes, one of the most powerful and enduring propositions in industrial relations was developed by Commons (1910): that the expansion of the market reduces labour's bargaining power unless institutions - unions or government - "adapt accordingly and take wages out of competition." Hoxie (1921) argued that for this to happen wage earners in similar social and economic environments had to develop a common interpretation of the social situation.

The decade from the mid-1950s to the mid-1960s saw the release of what were destined to become two classics of industrial relations literature: Dunlop's Industrial Relations Systems (1958) and Walton and McKersie's A Behavioral Theory of Labor Negotiations (1965). In this period following World War II, the study of unionism came to focus increasingly on the collective bargaining outcomes achieved by unions. Through this period, the status of unions as the institutional voice of workers was reinforced. The union as an institution was reflected through its practice of collective bargaining. Kerr (1964) exemplified writers who began to study each union as a bargaining agent for a sectional constituency, rather than seeing the union movement only as a homogeneous monolith with a single quantitatively definable objective. 
Changes in managerialism resulting from economic upheaval since the 1970 s have led scholars to question whether a new and distinct form of industrial relations is developing in the modern era (Kochan, Katz and McKersie, 1987). A general theme of industrial relations writing in the modern era is that declining unionism, employer initiative in bargaining, the spread of alternative forms of worker representation, and increased decentralisation of workplace regulation have diminished the role of trade unions, and demoted the importance of trade unions in research. The upsurge in attention to managerial needs and initiatives is consistent with this perspective.

Recent industrial relations change in New Zealand has been at least as dramatic as elsewhere, and the focus of research has naturally followed in the direction of change. Research on employment contract formation in New Zealand today necessarily goes beyond a sole focus on unionised collective bargaining. Workers have representation options that were widely promoted by the architects of the ECA, and employers have options as well. Research now focuses on a range of processes and the outcomes which flow therefrom.

This paper explores the outcomes produced by the various processes of employment contract formation available and practiced in the modern New Zealand labour market. Amidst the variety of new approaches, the enduring theme of the role of trade unions as a vehicle for effective employee voice in the determination of terms and conditions of employment receives strong support yet again, in this very different time and place than those envisioned by most industrial relations writers over the past 100 years.

\section{The previous research}

The data for this paper and for the previous papers referenced are drawn from a 1992 postal survey of a random sample of approximately 1800 employing units across all industrial classifications, workforce sizes and geographical areas of New Zealand. Useable responses were received from a total of 557 organisations, of which 371 had implemented new employment contracts, either individual contracts, collective contracts or both. The postal survey has subsequently been followed by indepth interviews with selected subsamples of employers.

\section{Explaining contract status and structure}

An earlier paper (McAndrew, 1992) examined evolving patterns of "contract status" under the bargaining provisions of the ECA. The notion of "contract status" embraced both the existence or not of a new employment contract of any type, and whether a new contract was an individual or a collective contract. Many employers in the sample had not made any formal moves, and some no moves at all, towards developing new contracts.

Two variables were found to be associated with a greater likelihood of employees being covered by new contracts developed under the Act. The larger the workforce, the more likely it was that employees were covered by new contracts; and, employees were more likely to be covered by new contracts if the employer had perceived union interference in 
the workplace as having been a problem in the past. Union interference was taken as a proxy for the level of union activity impacting the workplace.

Workforce size and a different measure of union presence -- pre-Act union membership -proved to be associated with the pattern of contract structures amongst workforces with new contracts. Individual contracts were most likely in small firms with low pre-Act union memberships, while collective contracts were most likely amongst larger workforces with high pre-Act union memberships. No other of a range of organisational and industrial relations variables -- including measures of employer needs -- emerged from regression analysis as associated with either aspect of contract status.

When combined with analysis of the pattern of employee concessions in new contracts, the data provided significant support for the notion that the Act would discriminate in favour of employees well organised in effective unions prior to the implementation of the Act. Using an "adoption rate" analysis similar to that discussed below, the earlier paper demonstrated that employee concessions during the formation of new contracts were significantly more likely under individual contracts than under collective contracts. Indeed, there was little evidence of effective employee resistance to employer-proposed concessions in the development of new individual contracts, whereas there was some such resistance in some instances of new collective contract development. Where an employer proposed an employee concession in the formation of a new individual contract, it was very likely to be adopted. Where an employer proposed an employee concession in the formation of a new collective contract, it was again likely to be adopted, but significantly less likely than was the case with individual contracts.

The extent to which employees yielded concessions, and particularly the rate at which employee concessions proposed by employers were in fact incorporated into new contracts, have been developed in this paper as a measure of negotiation behaviour in new contract development.

\section{Models of collective contract formation}

As noted, the disparity in the adoption rate of employer-proposed employee concessions between new individual contracts and new collective contracts, and a corresponding disparity in perceived productivity improvements as well, were at statistically significant levels. Nonetheless, it was noted in the earlier analysis that both gaps were "somewhat diminished by a hybrid model under which some employers compiled collective contracts by dealing individually with each employee to be covered by the contract, and to a lesser extent by employers who dealt directly with their workforces as a whole rather than with representatives of the workforce." (McAndrew, 1992: 266)

This indication that not all collective contracts under the Employment Contracts Act have been created equally was further developed in a second paper. Evidence of three distinct models amongst the 223 reporting organisations with collective contracts was described as follows: 
In 51 firms ( 23 percent), collective contract terms were developed through direct negotiations with the staff as a whole or in work groups, without union or other representation.

In 46 firms (21 percent), employees were signed onto the collective contract essentially individually, and again without representation...(T)here are several sub-models in this category, but what they have in common is that any negotiation and agreement to the contract were handled at the individual level between the employer and employee.

The third category of 126 firms (56 percent) engaged in more conventional collective bargaining with authorised representatives of the employees to be covered by the contract. (McAndrew, 1993: 172)

A description and analysis of each approach led to the following conclusion:

At a time of widespread employee concessions in New Zealand, only the representative collective bargaining model exhibits in its logistics and outcomes the sort of give and take conventionally associated with bargaining behaviour in the industrial relations arena...Firms operating under this model...tended to be somewhat more aggressive in seeking employee concessions in the transition to new contracts, and were significantly less likely than others to get all that they sought. (McAndrew, 1993: 182)

In almost all instances in the sample, this model involved union representation. On the other hand, conventional bargaining behaviour was not widely evident in either of the other models of collective contract formation. For the most part, initial management proposals tended to be accepted with only minor, if any, modifications and with little debate.

The starting point for the extension of this earlier analysis in the present paper was to test the hypothesis that the same explanatory variables seen to be associated with the distribution of individual versus collective contracts would also explain the distribution of the three collective contracting models. Specifically, it was postulated that the representative collective bargaining model would predominate amongst larger workforces, amongst workforces with high pre-Act union membership, and perhaps amongst workforces whose employers had been bothered by union interference in the past.

\section{The distribution of collective contracting models}

Consistent with the earlier analysis of contract structures reported above, the distribution of the three collective contracting models was initially tested for the present paper against three primary organisational variables and three primary industrial relations variables.

\section{$\underline{\text { Organisational variables }}$}

The organisational variables were: (1) the size of the workforce, as measured by the total number of the respondent organisation's employees covered by union-negotiated documents in the pre-Act era; (2) the industrial classification or main business of the organisation; and (3) the extent of felt pressure to reduce production costs. Throughout the research, a number of other organisational variables, including whether the organisation was affiliated with a larger organisation or was independent, the number of places of business, and the gender makeup of the workforce have been found to be associated with these three principal organisational variables. Accordingly, they are not examined separately here. 
Whereas contract structure, on the individual versus collective dimension, was associated only with workforce size, Chi-square tests suggested that the distribution of collective contracting models amongst those organisations with collective contracts was significantly associated with all three organisational variables tested. As expected, larger workforces were more likely to have been involved in the representative collective bargaining process. The other two approaches were more likely amongst smaller workforces, though with no apparent pattern of distribution between the group and individual employee approaches.

Collective bargaining through representatives was disproportionately apparent, among those with collective contracts, in the primary, building and construction, and the transport, storage and communications industry sectors, though it should be noted that at least the first two of these had relatively little collective contracting overall. The most even distribution amongst the three models was in the retail sector, though again there were no pronounced patterns of distribution between the group and individual employee approaches.

Table One presents the distribution of collective contracting models by reported felt pressure to reduce production costs. Most apparent on the face of Table One is the direct relationship between the level of pressure to reduce production costs and the likelihood of having been involved in representative collective bargaining, previously noted as a process which almost always involved dealing with union representatives. Once again, the distribution between the other two models shows no clear pattern, other than the 50 percent individual approach among organisations feeling little or no pressure, but the numbers in that category are very small.

Table One: collective contracting models by production cost pressures

Level of Pressure

Interaction

with Groups

(CECs Group)
Interaction

w/ Individs

$\underline{\text { (CECs Indiv) }}$
Interaction

w/ Representatives

(CECs Reps)

to Reduce Costs

Little or none

$(\mathrm{n}=8)$

2

(25\%)

4

$(50 \%)$

2

(25\%)

Some

23

10

34

$(\mathrm{n}=67)$

(34\%)

(15\%)

$(51 \%)$

A great deal

18

24

57

$(\mathrm{n}=99)$

$(18 \%)$

$(24 \%)$

Intense

8

$(16 \%)$

8

33

$(16 \%)$

$(67 \%)$ 


\section{$\underline{\text { Industrial relations variables }}$}

Again consistent with earlier work, the industrial relations variables against which the distribution of collective contracting models was tested were: (1) the nature of the unionnegotiated document (and whether there was one) covering the largest number of the organisation's employees in the pre-Act period; (2) the pre-Act percentage of union membership among employees covered by that document, as estimated by the respondent employer; and (3) whether the respondent perceived "outside union interference" to have been a problem for the organisation in the period before the Act. As noted above, in the earlier analysis of contract status, union interference showed through as predictive of having new contracts in place, while high pre-Act union membership suggested that those contracts would be collective. For the present purposes, at least the union membership variable was expected to be associated with the distribution of the collective contracting models.

In fact, on the basis of Chi-square tests, neither the union interference variable nor the union membership variable were associated with the distribution of the three models of collective contract formation, though in the latter case it should be noted that close to 80 percent of organisations with collective contracts were in the "high union membership" category (76-100 percent membership). Interestingly, the nature of the pre-Act document was related to the distribution of the models, with the representative model more likely among those organisations with any "local" document -- enterprise agreement, parent company agreement, or local or regional award -- than among those organisations which had dealt only with national awards. No pattern was apparent in the more limited distribution of just the group and individual employee approaches to collective contracting.

Given the somewhat unexpected pattern of relationships suggested by Chi-square testing, the variables were subjected to logistic regression analysis. Only workforce size proved a significant (probability of $<.01$ ) predictor amongst the three models.

As with earlier papers, there was no evidence in the data to suggest that labour relations arrangements under the Employment Contracts Act were being tailored to the needs and circumstances of particular employing organisations, with neither industrial classification nor the pressure factor surviving the regression analysis. At the same time, the apparent insignificance of the key industrial relations variables in explaining the distribution of the three approaches to collective contract formation suggested that the three model framework was perhaps not the most appropriate framework for analysing approaches to contract formation under the ECA, and that a different basis for categorisation might be more illuminating. This in turn led on to the analysis that fills the balance of this paper.

\section{"Adoption rate" analysis}

A significant portion of the survey questionnaire from which the data reported in this paper are drawn consisted of a number of stated "problems" that proponents of the Employment Contracts Act attributed to the pre-Act industrial relations system, and that they branded as detracting from productivity and performance in New Zealand firms. Each survey respondent was asked to indicate whether, in fact, the stated "problem" had been seen as 
a problem in his or her organisation before the implementation of the Act and, if so, which if any of the solutions accompanying the problem statement (or any other solutions of their own invention) were proposed, and if proposed adopted, in the transition to new contracts.

Virtually all of the employers who had implemented new contracts identified with one or usually more of the problems cited, and had proposed and adopted various solutions. Not all of the solutions proposed would be considered concessions on the part of employees, but many of them would. Only solutions that would most obviously and widely be considered employee concessions were used in calculating "adoption rates."

The "adoption rate", for purposes of this analysis, is that proportion of employers proposing an employee concession who were successful in having the concession incorporated in new contracts installed under the Act. The adoption rate analysis is used below to examine the practical differences between the four models of employment contracting identified in the research: individual contracting and the three models of collective contracting. The "IEC Only" category used in the analysis includes only organisations that, at the time of the survey, had implemented new individual employment contracts (IECs), but had not implemented any collective employment contracts (CECs). Firms that had implemented both types are assigned to the appropriate "CEC" category.

There were a total of 15 substantive problems presented to respondents for reaction, in addition to the "union interference" problem referenced above and which is not included in the adoption rate analysis. Table Two details, for purposes of perspective, the percentage of respondents within each contracting model who identified with the six problems most often acknowledged by the survey respondents. Each of these six problems was claimed as a pre-Act problem by more than one-third of the respondents. It should be acknowledged that aggregate numbers vary slightly across the analysis that follows due to occasional incomplete or indecipherable responses to particular questions.

Though there are some suggestive patterns in Table Two, identification with these six, or indeed the full list of problems was not distributed amongst employers in the various contracting options in a statistically significant way. 
Table Two: Problems acknowledged by contracting model

$\%$ of respondents identifying with problem

$\underline{\text { Short statement of problem }}$

$\begin{array}{llll}\text { IECs } & \text { CECs } & \text { CECs } & \text { CECs } \\ \text { Only } & \text { (Group) } & \text { (Indiv) } & \text { (Reps) } \\ (n=143) & (n=51) & (n=46) & (n=126)\end{array}$

Restrictions on working shifts

$55 \%$

$60 \%$

$44 \%$

$72 \%$

Restrictions on weekend work

$60 \%$

$64 \%$

$67 \%$

$71 \%$

Restrictions on redundancy

$48 \%$

$39 \%$

$33 \%$

$46 \%$

Pay unrelated to performance

$46 \%$

$37 \%$

$27 \%$

$43 \%$

Inflexible work schedules

$35 \%$

$43 \%$

$37 \%$

$54 \%$

Excessive/unreas compensation

$49 \%$

$53 \%$

$48 \%$

$57 \%$

Table Three identifies all ten employee concessions reported as having been adopted by more than one-fifth of the total survey sample of 557 organisations, as solutions to one or another of the six most often cited problems identified in Table Two. The adoption rate is expressed as a percentage and, again, represents the proportion of employers proposing the employee concession who were in fact successful in having the concession incorporated in new contracts. 
Table Three: Adoption rate of employee concessions proposed by employers

\begin{tabular}{|c|c|c|c|c|}
\hline Short statement of solution & $\begin{array}{l}\text { IECs } \\
\text { Only } \\
(n=143)\end{array}$ & $\begin{array}{l}\text { CECs } \\
\text { (Group) } \\
(\mathrm{n}=51)\end{array}$ & $\begin{array}{l}\text { CECs } \\
\text { (Indiv) } \\
(n=46)\end{array}$ & $\begin{array}{l}\text { CECs } \\
\text { (Reps) } \\
(n=126)\end{array}$ \\
\hline $\begin{array}{l}\text { Expanding the definition } \\
\text { of normal hours }\end{array}$ & $\begin{array}{l}\mathbf{8 3} \% \\
{[59 / 71]}\end{array}$ & $\begin{array}{c}86 \% \\
{[24 / 28]}\end{array}$ & $\begin{array}{l}\mathbf{1 0 0 \%} \\
{[19 / 19]}\end{array}$ & $\begin{array}{c}79 \% \\
{[65 / 82]}\end{array}$ \\
\hline $\begin{array}{l}\text { Eliminating the definition } \\
\text { of normal hours }\end{array}$ & $\begin{array}{l}90 \% \\
{[47 / 52]}\end{array}$ & $\begin{array}{c}82 \% \\
{[14 / 17]}\end{array}$ & $\begin{array}{l}\mathbf{1 0 0} \% \\
{[10 / 10]}\end{array}$ & $\begin{array}{c}\mathbf{6 5 \%} \\
{[34 / 52]}\end{array}$ \\
\hline $\begin{array}{l}\text { Abolishing or reducing penal } \\
\text { rates for shift work }\end{array}$ & $\begin{array}{l}\mathbf{8 8} \% \\
{[59 / 67]}\end{array}$ & $\begin{array}{l}\mathbf{8 4 \%} \\
{[21 / 25]}\end{array}$ & $\begin{array}{l}\mathbf{1 0 0} \% \\
{[18 / 18]}\end{array}$ & $\begin{array}{c}\mathbf{8 0} \% \\
{[52 / 65]}\end{array}$ \\
\hline $\begin{array}{l}\text { Removing restrictions on } \\
\text { weekend work }\end{array}$ & $\begin{array}{c}\mathbf{8 6 \%} \% \\
{[37 / 43]}\end{array}$ & $\begin{array}{l}94 \% \\
{[17 / 18]}\end{array}$ & $\begin{array}{c}\mathbf{9 4 \%} \\
{[15 / 16]}\end{array}$ & $\begin{array}{c}69 \% \\
{[24 / 35]}\end{array}$ \\
\hline $\begin{array}{l}\text { Abolishing or reducing penal } \\
\text { rates for weekend work }\end{array}$ & $\begin{array}{l}\mathbf{8 6} \% \\
{[79 / 92]}\end{array}$ & $\begin{array}{c}86 \% \\
{[24 / 28]}\end{array}$ & $\begin{array}{c}\mathbf{8 9} \% \\
{[25 / 28]}\end{array}$ & $\begin{array}{l}87 \% \\
{[67 / 77]}\end{array}$ \\
\hline $\begin{array}{l}\text { Abolishing or reducing } \\
\text { redundancy payments }\end{array}$ & $\begin{array}{c}\mathbf{8 4 \%} \\
{[49 / 58]}\end{array}$ & $\begin{array}{c}90 \% \\
{[18 / 20]}\end{array}$ & $\begin{array}{c}\mathbf{9 3} \% \\
{[13 / 14]}\end{array}$ & $\begin{array}{l}69 \% \\
{[29 / 42]}\end{array}$ \\
\hline $\begin{array}{l}\text { Future pay increases to be } \\
\text { exclusively performance based }\end{array}$ & $\begin{array}{l}\mathbf{8 3} \% \\
{[49 / 59]}\end{array}$ & $\begin{array}{c}\mathbf{8 7} \% \\
{[13 / 15]}\end{array}$ & $\begin{array}{l}75 \% \\
{[6 / 8]}\end{array}$ & $\begin{array}{c}78 \% \\
{[18 / 23]}\end{array}$ \\
\hline $\begin{array}{l}\text { Management authorised to vary } \\
\text { start/finish times as required }\end{array}$ & $\begin{array}{c}82 \% \\
{[41 / 50]}\end{array}$ & $\begin{array}{l}77 \% \\
{[17 / 22]}\end{array}$ & $\begin{array}{c}83 \% \\
{[10 / 12]}\end{array}$ & $\begin{array}{c}\mathbf{8 0} \% \\
{[42 / 52]}\end{array}$ \\
\hline $\begin{array}{l}\text { Abolishing or reducing some } \\
\text { or all wage premiums }\end{array}$ & $\begin{array}{l}86 \% \\
{[38 / 44]}\end{array}$ & $\begin{array}{c}92 \% \\
{[12 / 13]}\end{array}$ & $\begin{array}{l}\mathbf{1 0 0} \% \\
{[14 / 14]}\end{array}$ & $\begin{array}{l}79 \% \\
{[31 / 39]}\end{array}$ \\
\hline $\begin{array}{l}\text { Abolishing or reducing some } \\
\text { or all allowances }\end{array}$ & $\begin{array}{c}91 \% \\
{[43 / 47]}\end{array}$ & $\begin{array}{c}89 \% \\
{[17 / 19]}\end{array}$ & $\begin{array}{l}\mathbf{8 8 \%} \\
{[14 / 16]}\end{array}$ & $\begin{array}{c}86 \% \\
{[43 / 50]}\end{array}$ \\
\hline
\end{tabular}

\section{Testing the adoption rates}

Statistical testing applied to the figures in Table Three showed no significant differences between the adoption rates in the process of developing individual employment contracts and in the two approaches to putting in place collective employment contracts that involved direct interaction with staff. By contrast, the adoption rate of proposed employee concessions in the process of dealing with employee representatives to develop collective employment contracts was shown to be significantly different (at the $\mathrm{p}<.01$ level in T-tests) to that for individual employment contracts, and to those in each of the other two approaches to developing collective employment contracts. 
The tests indicate that, at least as gauged by this adoption rate measure, individual contracting, the development of collective contracts by direct interaction with staff as a whole or in groups, and the compilation of collective contracts by direct dealings with employees individually are really three variations of the one approach to employment contract formation. At least in their outcomes they are indistinguishable from one another, though separately or together they are distinguishable from the approach of developing collective contracts by dealing with representatives of employees, representatives who in this study were almost always union officials. This finding is, of course, not inconsistent with the conclusion in an earlier paper that only in the representative collective contracting process was there any evidence of conventional bargaining behaviour by the parties. In essence, there appear to be, instead of four distinct approaches to contract formation, just two: a negotiation model and a non-negotiation model, albeit that the latter has a number of variations.

These results suggested that a comparison of the adoption rates for the representative collective bargaining approach (the negotiation model) on the one hand, and collectively for the three other approaches to contracting (the non-negotiation model) on the other hand would be appropriate. Predictably, the adoption rates and patterns in this head-to-head comparison proved highly significantly different $(\mathrm{p}<.0001)$, whether measured by the adoption rates for the most often proposed or adopted employee concessions, or by those for the complete list of employee concessions, or by those for the full list of "solutions" incorporating both employee concessions and other solutions to problems seen by respondents to exist in their workplaces. Solutions not classified as concessions included such measures as additional training, profit sharing, greater consultation, standardizing allowances at the highest rate, and so on. By any list of concessions or solutions, the adoption rates and patterns for the firms engaged in representative collective bargaining were significantly different from those for the other three approaches to contract formation taken together, while the adoption rates and patterns did not differ significantly among these other three approaches.

\section{Holding the line in negotiations}

For the most part, the adoption rate of employee concessions and solutions proposed by the employer was not merely different, but lower in the representative collective bargaining process than in any or all of the other processes. This was not always so, but it was almost always so. At the bottom line, employers were significantly less successful in having their proposals adopted when dealing with employee representatives in the negotiation of collective contracts than was the case in any of the three non-negotiation approaches to contract formation; on the other hand, their success rate did not differ significantly among these other three approaches. There have evolved under the Employment Contracts Act, then, a largely unionised negotiation model of collective contracting, and a largely nonunion non-negotiation model of contracting. The latter has, at a cosmetic level, several variations, and it may lead to either individual or collective contracts. In terms of the process and its outcomes, however, the variations have in common that there is little or no negotiation or movement by employers from their initially proposed contract terms. 
While this paper is not the place for a detailed discussion of the nature of employee concessions under the Act, the areas in which employees represented by unions in the negotiation model are "holding the line" by most dramatic comparison with concessions extracted from employees in the non-negotiation model is of interest. Table Four lists those employee concessions which exhibited the greatest adoption rate margins between employers in the negotiation model and those in the non-negotiation model. The list is confined to just those concessions where there was more than a 35 point margin between the adoption rates in the two models.

\section{Table Four: Adoption rate comparison of employee concessions exhibiting the largest adoption rate margins between the negotiation and non-negotiation models}

$\begin{array}{lccc}\text { Short statement of concession } & \begin{array}{l}\text { Adoption rate } \\ \text { non-negotiation } \\ \text { model employers }\end{array} & \begin{array}{l}\text { Adoption rate } \\ \text { Negotiation } \\ \text { model employers }\end{array} & \begin{array}{l}\text { Percentage } \\ \text { Points } \\ \text { Margin }\end{array} \\ \begin{array}{l}\text { Permanent staff replaced by } \\ \text { contractors }\end{array} & 80 \% & 25 \% & 55 \% \\ \begin{array}{l}\text { Permanent staff replaced by } \\ \text { temporary or casual staff }\end{array} & 83 \% & 29 \% & 54 \% \\ \begin{array}{l}\text { Contracting out specified } \\ \text { types or pieces of work }\end{array} & 83 \% & 40 \% & 43 \% \\ \begin{array}{l}\text { Introducing or authorising } \\ \text { short or split shifts }\end{array} & 91 \% & 50 \% & 41 \% \\ \begin{array}{l}\text { Abolishing restrictions on } \\ \text { the right to lay off staff }\end{array} & 86 \% & 46 \% & 40 \% \\ \begin{array}{l}\text { Standardize penalty rates, } \\ \text { allowances etc at lowest award } \\ \text { rates applicable to any staff }\end{array} & 71 \% & 31 \% & 38 \% \\ \begin{array}{l}\text { Authorise standing down staff } \\ \text { for part shift for lack of work }\end{array} & 67 \% & & 36 \% \\ \end{array}$

for part shift for lack of work

As might be expected, none of the most common employee concessions as identified in Table Three show up in Table Four. Even strong unions in negotiations for collective contracts have not been widely successful in resisting such concessions as the rolling back or at least modification of penal rates and redundancy pay. On the other hand, there is a very clear imprint on the list of concessions in Table Four. With only one exception, the concessions on which unions have comparatively held the line in negotiations most successfully, at least on the basis of adoption rates as defined, all relate to job or work security -- the protection of permanent, full-time jobs against erosion by contracting, employment of short-term staff, redundancy, or cutting into the work shift. 


\section{Factors associated with the negotiation model}

It remains to examine the distribution of the negotiation and non-negotiation models with reference to the three organisational and three industrial relations variables employed throughout the analysis. In Chi-square tests, only industrial classification and felt pressure to reduce production costs showed no significant association with the distribution of the negotiation and non-negotiation models. The negotiation model showed up in Chi-square tests as positively associated with larger workforces $(\mathrm{p}<.0001)$, higher pre-Act union membership $(\mathrm{p}<.001)$, "local" pre-Act documents as previously defined $(\mathrm{p}<.01)$, and the perception of pre-Act union interference as a problem $(\mathrm{p}<.04)$. In logistic regression analysis, only workforce size $(\mathrm{p}<.0001)$ and pre-Act union membership $(\mathrm{p}<.03)$ retained significance, with workforce size clearly having the highest explanatory value.

The distribution of the negotiation and non-negotiation models by workforce size are presented in Table Five. With the exception of a slight reversal amongst the very largest workforces, the table illustrates a fairly direct and positive relationship between workforce size and the likelihood of an employer having negotiated with employee representatives over a collective contract. As noted, the explanatory value of pre-Act union membership was significant but less dramatic. On a two category classification, employers reporting preAct union membership amongst their eligible employees at higher than 75 percent were twice as likely ( 45 percent versus 22 percent) to be in the negotiation model.

Table Five: Negotiation and non-negotiation models by workforce size

\begin{tabular}{lll} 
Workforce Size & \multicolumn{2}{c}{$\begin{array}{l}\text { Numbers and percentages of employers } \\
\text { Non-negotiation }\end{array}$} \\
$\begin{array}{lll}\text { Model (n=232) } \\
1-25 \text { employees }\end{array}$ & $\begin{array}{l}\text { Negotiation } \\
\text { Model (n=124) }\end{array}$ \\
$26-50$ employees & $47(61 \%)$ & $30(19 \%)$ \\
$51-100$ employees & $27(52 \%)$ & $25(48 \%)$ \\
$101-200$ employees & $13(38 \%)$ & $21(62 \%)$ \\
$201+$ employees & $14(44 \%)$ & $18(56 \%)$
\end{tabular}

To further examine the distribution of the models against the variables, the data were subjected to CHAID analysis. CHAID (Chi-squared Automatic Interaction Detector) divides a population into two or more distinct groups based on categories of the "best" predictor of a dependent variable. It then splits each of these groups into smaller subgroups based on other predictor variables. This splitting process continues until no more statistically significant predictors can be found (Magidson, 1992). 
A CHAID display takes the form of a tree diagram. Figure One is a diagrammatic representation of the variables predicting the distribution of the negotiation and nonnegotiation models.

\section{Figure One: Distribution of negotiation and non-negotiation models}

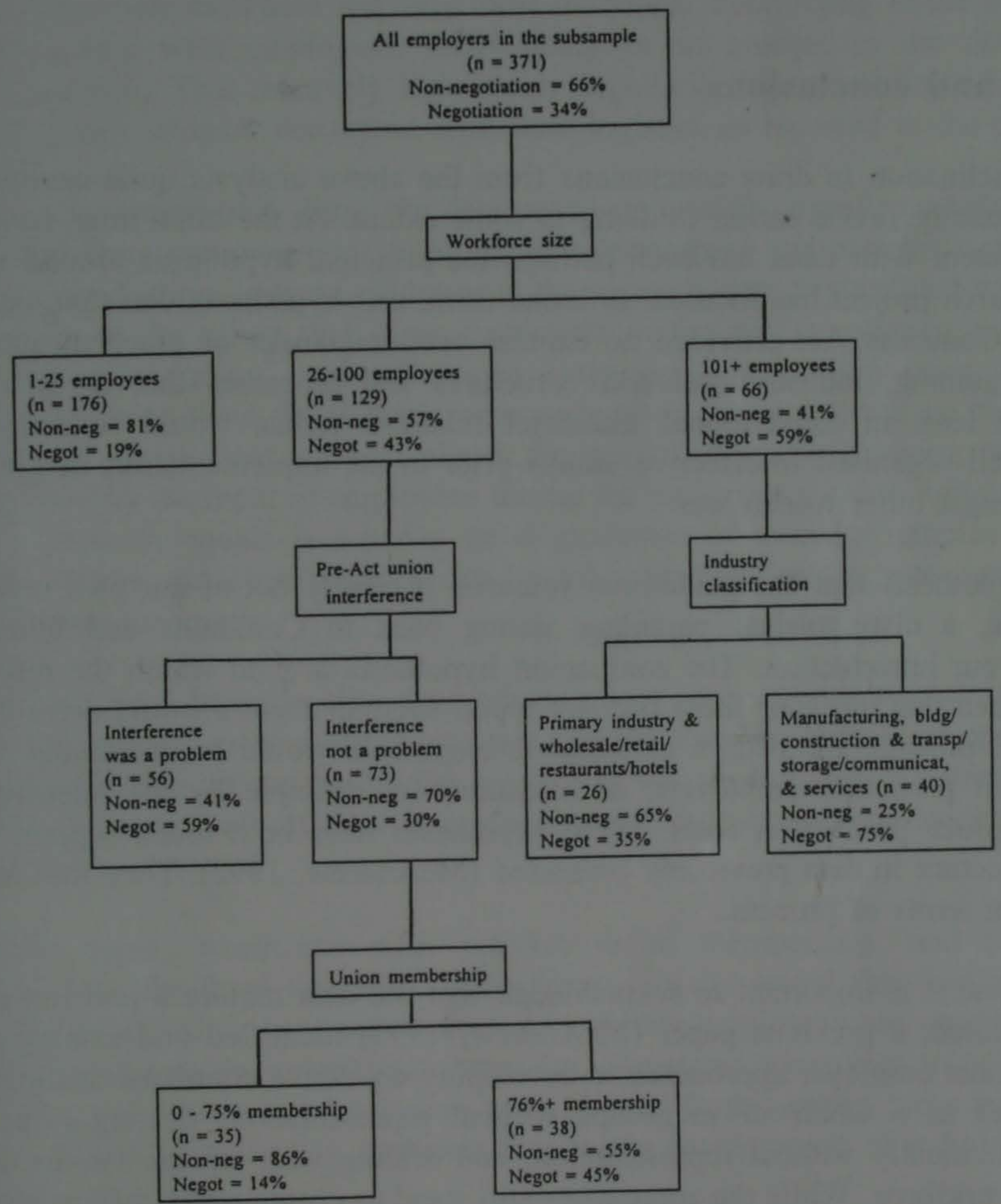

As illustrated in Figure One, the CHAID analysis both confirms and expands upon the regression analysis. Clearly, the best predictor of an employer being in the negotiation model is workforce size. Though an exception was noted at the top end in the earlier regression analysis using a more extensive categorization of workforce size, it is generally true that the larger the workforce, the more likely it is that an employer will have engaged in negotiation with a union over a collective employment contract.

From that point, the analysis segments the population by significant variables. For employers in the smallest workforce size, no further statistically significant predictors of negotiation were found. For employers with mid-size workforces, those that had experienced union interference as a problem before the passage of the Act were 
significantly more likely than others to have negotiated with unions for a collective contract. For those that had not experienced union interference as a problem in the past, the second indicator of union strength or presence -- high union membership -- showed up as an additional predictor of negotiations. For employers in the largest workforce category, industry was a significant variable, with those in the primary industry and the retail and wholesale industrial classifications less likely than others to have engaged in negotiations.

\section{Discussion and conclusions}

There is an inclination to draw conclusions from the above analysis quite cautiously. The findings necessarily revise earlier thinking to some extent. At the same time, however, the data are consistent with what has been perhaps the principal hypothesis around which the on-going research project has focused. In broad form, that hypothesis was that, because the Employment Contracts Act provided no express encouragement or practical supports for collective bargaining, industrial relations structures and processes that are effective for employees, at least in conventional industrial relations terms, would be found among workforces well organised in effective unions prior to the implementation of the Act, but not often amongst other workforces.

This broad hypothesis that has guided our research is clearly not of our own invention. It has, of course, a distinguished parentage dating back to Commons and other writers referenced in our introduction. The companion hypothesis around which the research has focused has been that, because these pre-Act union strength factors would drive employee relations developments, the pattern of those developments would be essentially unrelated to the needs of particular employers, as measured for example by the intensity of felt pressures to reduce production costs. These hypotheses have both found support in terms of contract structure in data previously presented (McAndrew, 1992). They find additional support here in terms of process.

Having said that, it is important to acknowledge that the data require a revision of earlier thinking. As noted, a previous paper (McAndrew, 1993) identified and catalogued three apparently distinct employer approaches to developing collective contracts: dealing directly with employees as a whole or in groups without representation, dealing directly with employees individually without representation, and dealing with representatives acting on behalf of the workforce. While the approaches still stand as cosmetically different strategies or at least styles, the significance of this categorisation of employer approaches to developing employment contracts is effectively denied by the further analysis in the present paper.

If adoption rates as defined are accepted as a measure of the give and take, the concession and compromise of negotiation, then it is apparent from the data that there are really only two distinct approaches to employment contracting under the Act. There is the negotiation approach that almost always in this study involved employers dealing with union officials representing the workforce. The logistics of that process have been described in the 1993 paper. The present analysis indicates that there is a significant degree of employer compromise in that negotiation process, and that finding is consistent with what came 
through in the earlier report as a relatively lengthy and demanding process, typically involving a number of meetings over several months and many hours of face to face negotiations.

And there is the non-negotiation approach which involves significantly less compromise of initial positions by employers in the formation of employment contracts. The nonnegotiation approach embraces not only most individual contracting in the study, but also the direct dealing with employees, individually or in groups, in the development of collective contracts. That relatively little if any negotiation is reported as occurring in any of these processes is again consistent with their logistics as reported in the earlier paper.

Two caveats are appropriate. First, the data report statistically significant relationships, not absolutes, and there are exceptions to all of the relationships and patterns suggested by the data. And, second, there is some evidence in the research data beyond that which has been presented here to the effect that some employers in the non-negotiation model engaged employees in consultation, and sometimes extensive consultation, prior to submitting contract proposals to them. In at least some such cases, while little or no movement may be evident in a negotiation sense or phase, the employer's early thinking may well have been influenced by the input of employees during the preliminary consultation phase. While negotiation between equals is a pretty good guarantee of effective employee input into employment terms and conditions, it can be acknowledged that it may not be the only effective avenue for input.

In the final analysis, however, the data reported here are consistent with earlier findings related to employment contract structures, and with the hypothesis that only employees well organised in effective unions before the passage of the Employment Contracts Act would be found to be doing well, at least in a conventional industrial relations sense, under the Act.

In the 1992 paper, workforce size, pre-Act union membership, and pre-Act union interference were the three variables of the many initially tested that had explanatory or predictive value regarding contract structures -- whether employers had employees covered by collective contracts developed under the Act. Structures were seen to be significant in that employee concessions, and adoption rates as used in this paper, were generally lower in the development of collective contracts than in the development of individual contracts.

Now in the present paper, the same three variables are seen to be associated with the probability that an employer is engaged in negotiation with union representatives for a collective contract, rather than essentially dictating employment terms via one of the three non-negotiation strategies. With the direct staff approaches to collective contracting being reclassified with individual contracting, the margin in concession taking between the negotiation and non-negotiation models, as measured by adoption rates, is even greater than that reported earlier between individual and collective contracts.

The evidence now suggests quite clearly that employers who were dealing with strong and effective unions before the passage of the Employment Contracts Act are likely to be still doing so. They tend, as might be expected, to be larger and medium sized organisations. On the other hand, employers who have not been confronted with strong and active unions 
in the past, many of them small organisations, are likely under the Act to have an essentially free hand to dictate employment terms to their employees. That they have used a variety rather than a uniformity of non-negotiation styles or strategies in implementing new contracts under the Act is not surprising given the lack of procedural requirements or guidelines in the Act.

It is appropriate to now pull together the various threads of our introductory discussion. The writers we surveyed from the institutional and collective bargaining eras, from the Webbs and Commons on down, would have predicted that, in the type of labour market sponsored by the Employment Contracts Act, workers would find effective voice through unions and collective bargaining, and only through unions and collective bargaining. And that the outcomes for those workers would be clearly distinguishable from the outcomes achieved by unorganised workers.

As Harbridge and Hince illustrate regularly and convincingly, the New Zealand labour market has become, under the ECA, a more discriminating labour market. The shrinking of unionisation, and its distribution, are a part of that pattern, and an ongoing part of the reason for it. Our findings are that only by means of collective dealing with employers through a bargaining agent, and leading to the formation of collective contracts, are workers able in the current environment to compel employers to negotiate. Where this process is in place, workers are almost always in our sample represented by a union. These groups of employees have been relatively successful in resisting employer demands for concessions.

Beyond this unionised collective negotiations sector, other groups of employees are being dealt with by their employers under a variety of approaches or strategies, mostly without employee representation, and resulting variously in individual or collective contracts. Our research indicates that these workers are not effective in modifying employer positions in any way that resembles negotiation and that, consequently, concessions have been extracted from these workers at a significantly higher rate than is the case for workers in the unionised collective negotiations sector. In a period of management initiative in employment relations, and in an environment tailored for it, unions practising collective bargaining comes through in our research, as has been the case for so long in industrial relations research and writing, as the vehicle in evidence for effective employee voice in the setting of terms and conditions of employment.

Boxall (1993) suggested a couple of years ago that, in most employing organisations in New Zealand, nothing had been done to date under the ECA which had seriously alienated the workforce. The mainstream employer, Boxall observed, knew that he or she was reaping the benefits of ongoing improvement in cost competitiveness, and was not so shortsighted as to jeopardise this situation. That may still be so. But equally, as indicated by Harbridge and Hince, a segmented and discriminatory labour market is now being cemented in place, and this has perhaps less immediately visible implications for employers as well as for employees.

Our research confirms the reports of others that the unionised segment of the New Zealand labour market is, to a considerable extent, protecting permanent, full-time jobs against erosion by contracting, employment of short-term staff, redundancy or compromise of the traditional work shift. Employees in the unrepresented sector have been less able to block 
or slow the move to such more flexible arrangements at the demand of their employers. As other commentators have recently remarked, unions are emerging in the labour market sponsored by the Employment Contracts Act as vehicles for the representation of "better off" workers, the elite of the labour market, as they cement in place and then enhance the gaps in job quality, wages and conditions that separate them from workers in the non-union, and essentially smaller-business segment of the market.

We made reference early on to the perceived enhancement of bargaining rights for already collectivised (unionised) groups of employees that is emerging from a succession of judicial interpretations of the bargaining and representation provisions of the ECA. Ironically, in the absence of legislative protections for employees wanting to collectivise in the face of employer opposition, then to the extent that the Employment Court continues to define the bargaining and representation provisions of the Act to enhance the collective bargaining rights of already unionised employees, as in the recent fire service case, the segmentation of the labour market into unionised and non-union workforces, with markedly different experiences of "industrial democracy" or effective employee voice, and markedly different job quality and wages and conditions can only become more pronounced over time.

Finally, as was concluded in the 1992 paper in relation to contract structures, there is little evidence that the negotiation versus non-negotiation dimension to employment contracting bears any relationship to the needs of particular employers. Industry classification shows up as a significant predictor, but only amongst the comparatively small segment of the largest employers, a segment that shows a relatively high negotiation rate overall. Otherwise, workforce size and union strength factors are seen to drive employee relations patterns and processes. As was the case with contract structures, neither the intensity nor sources of pressure to reduce production costs had any predictive value in terms of the likelihood of an employer being in the unionised negotiation or non-union, non-negotiation model, despite all of the implications of that distinction. This remains perhaps the ultimate irony of developments under the Act.

\section{References}

Anderson, Gordon (1991), The Employment Contracts Act 1991: An Employers' Charter? New Zealand Journal of Industrial Relations 16(2): 127-142.

Armitage, Craig and Richard Dunbar (1993), Labour Market Adjustment Under the Employment Contracts Act, New Zealand Journal of Industrial Relations 18(1): 94-112.

Boxall, Peter (1993), Management Strategy and the Employment Contracts Act 1991. In Harbridge, Raymond (Ed.) Employment Contracts: New Zealand Experiences, Wellington: Victoria University Press.

Commons, John R. (1910), A Documented History of American Industrial Society, San Francisco: Arthur Clark. 
Dunlop, John T. (1958), Industrial Relations Systems New York: Holt (Revised edition, 1993, Cambridge: Harvard Business School Press).

Freeman, Richard B. and James L. Medoff (1984), What Do Unions Do? New York: Basic Books.

Hammond, Suzanne and Raymond Harbridge (1993), The Impact of the Employment Contracts Act on Women at Work, New Zealand Journal of Industrial Relations, 18(1): 1530.

Harbridge, Raymond and Kevin Hince (1994), Bargaining and Worker Representation under New Zealand's Employment Contracts Legislation: A Review after Two Years Relations Industrielles, 49(3): 561-581.

Harbridge, Raymond and James Moulder (1993) Collective Bargaining and the Employment Contracts Act: One Year On. The Journal of Industrial Relations, 35(1): 62-83.

Harbridge, Raymond, Kevin Hince and Anthony Honeybone (1994), Unions and Union Membership in New Zealand. New Zealand Journal of Industrial Relations, 19(2): 175180.

Harbridge, Raymond, Kevin Hince and Anthony Honeybone (1995), Unions and Union Membership in New Zealand: Annual Review for 1994. New Zealand Journal of Industrial Relations (this volume).

Hince, Kevin and Raymond Harbridge (1994), The Employment Contracts Act: An Interim Assessment. New Zealand Journal of Industrial Relations, 19(3): 235-255.

Hoxie, Robert (1921), Trade Unionism in the United States New York: Appleton.

Kerr, Clark (1964), Labor and Management in Industrial Society, New York: Doubleday.

Kochan, Thomas A. (1995), Launching a Renaissance in International Industrial Relations Research. Proceedings of the 10th World Congress of the International Industrial Relations Association Madison, Wisconsin: Industrial Relations Research Association.

Kochan, Thomas A., Harry C. Katz and Robert B. McKersie (1987), The Transformation of American Industrial Relations, New York: Basic Books.

Magidson, Jay (1992), SPSS CHAID Version 5, Chicago: SPSS Inc.

McAndrew, Ian (1993), The Process of Developing Employment Contracts: A Management Perspective. In Harbridge, Raymond (Ed.), Employment Contracts: New Zealand Experiences, Wellington: Victoria University Press.

McAndrew, Ian (1992), The Structure of Bargaining Under the Employment Contracts Act, New Zealand Journal of Industrial Relations, 17(3): 259-282. 
Perlman, Selig (1928), A Theory of the Labor Movement, New York: McMillan.

Tannenbaum, Frank (1921), The Labor Movement, Its Conservative Functions and Social Consequences, New York: Putnams.

Walsh, Pat (1991), Bargaining Options Under the Employment Contracts Act, New Zealand Journal of Industrial Relations, 16(2): 167-174.

Walsh, Pat and Rose Ryan (1993), The Making of the Employment Contracts Act. In Harbridge, Raymond (Ed.), Employment Contracts: New Zealand Experiences, Wellington: Victoria University Press, 13-30.

Walton, Richard E. and Robert B. McKersie (1965), A Behavioral Theory of Labor Negotiations, New York: McGraw Hill (Revised edition, 1991, Ithaca, NY: ILR Press).

Webb, Sidney and Beatrice Webb (1896), A History of Trade Unionism London: Longmans.

Whatman, Richard, Craig Armitage and Richard Dunbar (1994), Labour Market Adjustment Under the Employment Contracts Act, New Zealand Journal of Industrial Relations, 19(1): 53-74. 